DOI: http://dx.doi.org/10.33846/hn40802

http://heanoti.com/index.php/hn

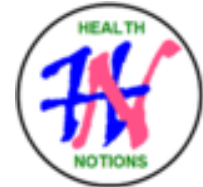

RESEARCH ARTICLE

URL of this article: http://heanoti.com/index.php/hn/article/view/hn40802

\title{
The Effect of Health Facilities and Waiting Time on Outpatient Satisfaction at Bondo Kodi Public Health Center
}

\author{
Ronaldus Asto Dadut ${ }^{1(\mathrm{CA})}$ \\ ${ }^{1(\mathrm{CA})}$ Department of Health Administration and Policy, Faculty of Public Health, Universitas Airlangga, \\ Indonesia; astodadut22@gmail.com (Corresponding Author)
}

\begin{abstract}
This study aims to analyze the influence of service quality, health facilities, and waiting times partially and simultaneously on outpatient satisfaction partially in the Bondo Kodi Public Health Center. This research was based on the results of preliminary observations that show the level of satisfaction of patien was still relatively low on health services provided. This research was explanatory research with quantitative approaches. This study was conducted in the Bondo Kodi Public Health Center. The population used in this study were all patients who had utilized health services. The sampling technique was done by purposive sampling, namely by using criteria. Data collection used questionnaires. Then the data analysis used was multiple linear regression analysis. The results of this study showed that service quality $(0.000)$, health facilities $(0.030)$, and waiting time (0.031) influence patient satisfaction at the Bondo Kodi Public Health Center. The results explained that improvements in the quality of services and health facilities will improve patient satisfaction, but at an increasingly shorter waiting time it will also increase patient satisfaction in Bondo Kodi Health Center.
\end{abstract}

Keywords: service quality; health facilities; waiting time; satisfaction

\section{INTRODUCTION}

Health has an important meaning because health is related to the entire environment around both inside and outside. Health cannot be underestimated by every human being because health is a human right and the nation's investment capital can affect the quality of human resources ${ }^{(1)}$. Therefore, each individual will try to achieve this health status by trying to obtain optimal health services. The high level of community education can make people more aware of the importance of quality. This awareness then encourages people to have a tendency to demand better and faster health services. The existence of public demand for better health services will encourage increasingly fierce competition between fellow hospitals, public health center, to health clinics in all regions ${ }^{(2)}$.

On the other hand, health service providers have an obligation to be able to provide health facilities and services in accordance with patient expectations. It aims to create satisfaction for patients ${ }^{(3)}$. In health services, satisfaction can be divided into two, namely satisfaction with the implementation of health service standards provided and satisfaction with the application of service requirements. If both types of satisfaction aspects can be fulfilled, the level of patient satisfaction will be in good condition ${ }^{(4)}$.

Satisfied patients are assets for health care institutions, because the patient concerned will continue to use the health services offered ${ }^{(5)}$. To be able to achieve these conditions, health care institutions need to better manage the service system and make improvements to health facilities. As also expressed by Harfika, et al. ${ }^{(3)}$ that every health care institution needs to know how to serve patients effectively and quickly. This is because the service has an orientation towards patient satisfaction. Patient satisfaction itself can be achieved when the health services received by patients are as expected, including health institutions in Bondo Kodi Public Health Center.

Based on observations made, it is known that there are delays in providing services to patients who come to the Public Health Center, thus causing longer waiting times to get health services. In addition, preliminary observations have also been made, some patients who have utilized health services complained about the condition of limited health facilities, such as a small examination room with poorly maintained medical 
equipment, waiting rooms and patient seating where inadequate number of visits occurred many patients, and toilets that need to be improved. Based on observations, because health support in Public Health Center is timeconsuming, it causes waiting time in service to be a bit late, so that there is anxiety from patients waiting to get service. Therefore, this study was conducted to analyze the factors that influence patient satisfaction at the Bondo Kodi Public Health Center. Factors studied include quality of service, health facilities and waiting time.

\section{METHODS}

This study used explanatory research with a quantitative approach. The study was conducted in July 2020. The population used was all patients who had and utilized health services at the Bondo Kodi Public Health Center, Southwest Sumba Regency, East Nusa Tenggara Province, Indonesia. The sampling technique was done by purposive sampling with outpatient criterias who have utilized the service three times in the last 6 months with patients over 16 years old. Based on the purposive sampling sample size used was 100 patients. Data collection techniques using a questionnaire which was then analyzed using multiple linear regression analysis.

\section{RESULTS}

Respondent characteristics consisted of gender, age, and the amount of utilization of health services carried out by each patient at the Bondo Kodi Public Health Center. In addition, also explained the results of descriptive analysis for each variable studied and the results of the analysis using multiple linear regression analysis. The description of each descriptive analysis results for each characteristic was shown as follows.

Table 1. Respondents characteristics based on gender, age, and utilization of health services in Bondo Kodi Public Health Center

\begin{tabular}{lcc}
\hline Gender & Frequency & Percentage \\
\hline Male & 62 & 62 \\
Female & 38 & 38 \\
\hline Age (years old) & & \\
\hline $23-28$ & 5 & 5 \\
$29-34$ & 21 & 21 \\
$35-40$ & 33 & 33 \\
$>40$ & 41 & 41 \\
\hline Frequency utilization & & \\
\hline 3-4 times & 60 & 60.0 \\
5-6 times & 25 & 25.0 \\
$>6$ times & 15 & 15.0 \\
\hline Total & 100 & 100 \\
\hline
\end{tabular}

Based on the results of the analysis shown in Table 1, it was known that the dominant patient utilizes health services at the Bondo Kodi Public Health Center was a male patient over the age of 40 years. Most patients who seek treatment have utilized the health services provided 3 to 4 times.

Table 2. Indicators of conditions for patient satisfaction in Bondo Kodi Public Health Center

\begin{tabular}{clc}
\hline Number & \multicolumn{1}{c}{ Indicators } & Mean \\
\hline 1 & Satisfied with the doctor, nurse, and patient relationship & 3.10 \\
2 & Satisfied with the convenience of service & 3.09 \\
3 & Have the freedom to make choices & 3.12 \\
4 & Satisfied with technical knowledge and competence & 3.15 \\
5 & Satisfied with service effectiveness & 3.17 \\
6 & Satisfied with the safety of the medical actions taken & 3.13 \\
\hline
\end{tabular}

Table 2 shows that each indicator of patient satisfaction shows a mean value of more than 3 , so as to explain that the level of patient satisfaction in outpatient care at the Bondo Kodi Public Public Health Center is high as indicated in the satisfaction with the effectiveness of the services shown by the officers, nurses, and doctors in charge. 
Table 3. Conditions for service quality indicators at the Bondo Kodi Public Health Center

\begin{tabular}{clc}
\hline Number & Indicators & Mean \\
\hline 1 & Tangibles & 3.11 \\
2 & Reliability & 3.21 \\
3 & Responsiveness & 3.14 \\
4 & Assurance & 3.20 \\
5 & Empathy & 2.86 \\
\hline
\end{tabular}

In the Table 3 showed empathy indicators have a mean value of less than 3 which explains that the majority of patients who have used outpatient care, the Bondo Kodi Public Health Center has not shown any concern in providing services that are in line with patient expectations. However, the Bondo Kodi Public Health Center is able to provide accurate and reliable services as indicated by the highest reliability indicator mean among other indicators.

Table 4. Conditions of service quality indicators in Bondo Kodi Public Health Center

\begin{tabular}{clc}
\hline Number & Indicators & Mean \\
\hline 1 & Consideration or partial planning & 2.90 \\
2 & Room design & 3.02 \\
3 & Equipment or furniture used & 2.77 \\
4 & Lighting & 3.00 \\
5 & Color & 3.01 \\
6 & Message delivered graphically & 3.06 \\
\hline
\end{tabular}

The results in Table 4 showed that the consideration or partial planning and equipment used has a mean value of less than 3, which explains that the patient feels uncomfortable with the condition of the bathroom in Bondo Kodi Health Center as a form of partial planning. In addition, patients also feel uncomfortable with the conditions of the equipment used to support health services. However, patients feel comfortable with the instructions contained in outpatient care, which can help patients easily utilize the health services in Bondo Kodi Public Health Center.

Table 5. Waiting time for health services in Bondo Kodi Public Health Center

\begin{tabular}{ccc}
\hline Waiting time & Frequency & Percentage \\
\hline$>60$ minutes & 37 & 37 \\
$<60$ minutes & 63 & 63 \\
\hline Total & 100 & 100 \\
\hline
\end{tabular}

The results in Table 5 showed that there were $63 \%$ of patients who stated that the waiting time to utilize services in outpatient care tends less than 60 minutes. This explained that the patient feels comfortable with waiting time to obtain services in Bondo Kodi Public Health Center outpatient clinic.

Table 6. Analysis of the effect of service quality, health facilities, and waiting time for health services in Bondo Kodi Public Health Center

\begin{tabular}{|c|c|c|c|c|c|}
\hline \multirow{2}{*}{ Variables } & \multicolumn{2}{|c|}{ Unstandardized Coefficients } & \multirow{2}{*}{$\mathrm{t}$} & \multirow{2}{*}{ Sig. } & \multirow{2}{*}{ Result } \\
\hline & $\mathrm{B}$ & Std. Error & & & \\
\hline (Constant) & 0.584 & 0.340 & 1.720 & 0.089 & \\
\hline service quality & 0.501 & 0.103 & 4.872 & 0.000 & Significant effect \\
\hline health facilities & 0.301 & 0.136 & 2.209 & 0.030 & Significant effect \\
\hline waiting time & -0.154 & 0.070 & 2.183 & 0.031 & Significant effect \\
\hline \multicolumn{3}{|c|}{ Fstatistic $=25.213$} & \multicolumn{3}{|c|}{$\mathrm{R}=0.664$} \\
\hline
\end{tabular}

Before carrying out multiple linear regression analysis, classic assumption testing has been done before to determine the ability of the model to produce a hypothesis test correctly. The classic assumption test results are included in the appendix. In Table 6, it explained that service quality (0.000), health facilities (0.030), and waiting time (0.031) influence patient satisfaction in Bondo Kodi Public Health Center. This is indicated by the significance value for each variable less than $5 \%$ or 0.05 . In Table 6 also shows the value of sig. The statistic is $0.000(<0.05)$ which explains that there is simultaneously a significant influence between service quality, health facilities, and waiting time. The indicated Rsquared value is 0.441 which explains that $44.1 \%$ of patient satisfaction at the Bondo Kodi Public Health Center can be explained by the quality of services, health facilities, and waiting times. 


\section{DISCUSSION}

Based on the results of the analysis that has been done, it is known that the quality of service, health facilities, and waiting time have a significant effect on patient satisfaction at the Bondo Kodi Public Health Center. The results of the study explained that improving the quality of services, improving available health facilities, and performing efficiently while waiting for services can increase patient satisfaction. The results of the study supported by Rehaman et.al (2018) added that increasing the provision of quality health services will be able to provide a good experience for patients so that satisfaction with health services is increasing ${ }^{(6)}$. Health facilities have a positive influence on patient satisfaction ${ }^{(7)}$. The availability of adequate and complete facilities can provide more optimal satisfaction for patients. The duration of waiting time can affect the affective aspects of the patient ${ }^{(8)}$. When the waiting time is getting shorter, it will be able to help patients to be satisfied with the services provided.

The aspect of facilities here plays an important role in being able to support an increase in patient satisfaction when waiting times are apparently not in line with patient expectations. When patients feel bored with long waiting times, the availability of supporting facilities such as the availability of air conditioners, entertainment facilities can help patients to get rid of saturation ${ }^{(9)}$. In addition, improvements in facilities will be able to support improvements in the quality of services provided at the Bondo Kodi Public Health Center to create patient satisfaction. This was also conveyed in a study by Supriyanto et.al (2012), that when the facilities available were able to meet patient expectations, they could indirectly improve the quality of services provided by the public health center.

\section{CONCLUSION}

Overall the results of the analysis and discussion show that improving the quality of services, health facilities and efficient waiting time for health services provided at the Bondo Kodi Public Health Center has a significant influence on patient satisfaction. Therefore, the Bondo Kodi Public Health Center can evaluate and monitor the performance of health workers, in order to maintain patient confidence in the quality of service. Also provides a central facility for complaints of patient complaints so that patients can channel their opinions on the services received. It also evaluates the performance of every doctor on duty at the Bondo Kodi Public Health Center and provides a substitute or backup doctor when the main doctor in charge is unable to attend or experiences obstacles to arrive on time, so that the time of the examination can be carried out according to the time promised to the patient. Bondo Kodi Public Health Center also needs to make a schedule for the maintenance of medical equipment and supporting furniture, to maintain the discipline of all related parties, both management, executor, or cleaning and maintenance staff to maintain the condition or immediately make a replacement or repair when the condition of the equipment or furniture does not support the provision health services at the Bondo Kodi Public Health Center.

\section{REFERENCES}

1. Maulana JDH. Health Promotion (Promosi Kesehatan). Jakarta: Penerbit Buku Kedokteran EGC. 2009

2. Indrayani TI, Welia. The Effect of Service Quality and Facilities on Patient Satisfaction in Siti Rahmah Islamic Hospital (Pengaruh Kualitas Pelayanan Dan Fasilitas Terhadap Kepuasan Pasien Di Rumah Sakit Islam (RSI) Siti Rahmah) . Journal of Menara Ekonomi. 2018;4(2).

3. Harfika J, Abdullah N. The Effect of Service Quality and Facilities on Patient Satisfaction at the General Hospital of Aceh Barat Daya District. Balance (Pengaruh Kualitas Pelayanan Dan Fasilitas Terhadap Kepuasan Pasien Pada Rumah Sakit Umum Kabupaten Aceh Barat Daya). 2017;14(01).

4. Octavia A, Suswitaroza, Anwar AP. Analysis of the Satisfaction of Patients in the Heart Ward at Raden Mattaher Hospital Jambi (Analisis Kepuasan Pasien Rawat Inap Bangsal Jantung di RSUD Raden Mattaher Jambi). Journal of Management in Jambi Economy Faculty Jambi. 2012;1(1).

5. Kreitz TM, Winters BS, Pedowitz DI. The Influence of Wait Time on Patient Satisfaction in The Orthopedic Clinic. Journal of Patient Experience. 2016;3(2): 39-42.

6. Rehaman B, Husnain M. The Impact of Service Quality Dimensions on Patient Satisfacton in The Private Healthcare Industry in Pakistan. Journal of Hospital \& Medical Management. 2018;4(1).

7. Supriyanto Y, Soesanto H. Analysis of The Effect of Service Quality, Price, and Facilities on Satisfaction of Outpatients at Kariadi Hospital Semarang (Analisis Pengaruh Kualitas Pelayanan, Harga, Dan Fasilitas Terhadap Kepuasan Pasien Rawat Jalan Di Rumah Sakit Kariadi Semarang). Diponegoro Journal of Management. 2012;1(1): 472-480.

8. Bielen F, Demoulin N. (2007). Waiting Time Influence on The Satisfaction-Loyalty Relationship in Services. Managing Service Quality: An International Journal. 2007;17(2):174-193. 